\title{
Church Music as Reflected in the Journal Biserica Ortodoxă Română [Romanian Orthodox Church] in the Second Half of the Twentieth Century
}

\author{
ELENA CHIRCEV, Professor PhD \\ "Gheorghe Dima" National Academy of Music Cluj Napoca \\ ROMÂNIA*
}

\begin{abstract}
The journal Biserica Ortodoxă Română [The Romanian Orthodox Church] was founded on November 17, 1873, at the initiative of Romania's Primate Metropolitan Nifon Rusailă (1789-1875). The aim of the publication - whose first issue was launched on October 1,1874 - was to inform the clergy and believers about the activity of the Holy Synod of the Romanian Orthodox Church. In the 146 years since the publication of its first issue, the journal's contributors have included outstanding personalities of the Romanian Orthodoxy, such as Priest-Professors Dumitru Stăniloae, Ioan G. Coman, Ene Branişte, Liviu Stan, Mircea Păcurariu, Ion Bria a.o. Church music was present in the journal's pages both through articles, studies and reviews, and through scores of choral or psaltic works written by Church servants among whom Bishop Melchisedec Ștefannescu of Roman at the end of the $19^{\text {th }}$ century, or Deacon Grigore Panțiru, Professor Nicolae Lungu, Priest-Professor Gheorghe S,oima, Archd. Sebastian Barbu-Bucur, Ph.D., Priest-Professors Constantin Drăgușin, Nicu Moldoveanu, Alexie Buzera a.o. in the $20^{\text {th }}$ century. This paper summarizes these contributions and shows how the change of political regime in mid$20^{\text {th }}$-century Romania influenced the topics of the articles and the religious musical works published in the journal of the Romanian Patriarchate.
\end{abstract}

Keywords: psaltic music, religious choral work, Byzantine musicology, manuscript, communism

\section{Introduction}

With an almost uninterrupted existence of 146 years, the journal Biserica Ortodoxă Română [The Romanian Orthodox Church] constitutes today a true documentary fund for those interested in the activity of the Holy Synod and of the clergy, in the theologians' preoccupations or in the spiritual life of the Romanian people, throughout different historical periods. The journal also indirectly reflects the transformations that the Orthodox Church underwent and the difficulties it faced during the communist period, alongside the entire Romanian society.

\footnotetext{
*elena_chircev@yahoo.co.uk
} 
From its very first decades of existence, the official publication of the Holy Synod offered a generous amount of content including over 23,000 various materials ${ }^{1}$, among which numerous articles and studies related to church music or musical folklore, reviews of choral works or scores and psaltic chants. Its authors include sonorous names of the Romanian culture from the end of the $19^{\text {th }}$ century - such as Constantin Erbiceanu, Bishop Melchisedec Ștefãnescu -, or from the interwar period - Patriarch Miron Cristea, Nicolae Iorga, Gala Galaction, Dumitru Stăniloaie, Dumitru Fecioru, Petre Vintilescu a.o. -, along with important personalities of Byzantine musicology or church music composers from the second half of the $20^{\text {th }}$ century, such as Gheorghe Ciobanu, Titus Moisescu, Archd. Sebastian Barbu-Bucur, PhD, Pr. Prof. Nicu Moldoveanu, PhD, Prof. Nicolae Lungu, Pr. Prof. Gheorghe Șoima, Pr. Prof. Alexie Buzera PhD, Viorel Cosma, Prof. Vasile Vasile, PhD.

The presence of the articles related to music (especially church music) in this journal occupied the attention of Prof. Nicu Moldoveanu, PhD, who coordinated the development of a general index entitled Index general al studiilor, articolelor, recenziilor, compozițiilor, prelucrărilor și armonizărilor de muzică bisercicească din revistele Patriarhiei Române [General Index of the Studies, Articles, Reviews, Compositions, Reworkings and Harmonizations of Church Music from the Journals of the Romanian Patriarchate] (2006). In 2014, the General Bibliography of the "Romanian Orthodox Church" Journal [Bibliografia generală a Revistei „Biserica Ortodoxă Română”] was published by Priest Alexandru Stănciulescu-Bârda and Cristian Stănciulescu-Bârda. In addition to synthesizing the contributions of the journal's authors to a better knowledge of church music and to the enrichment of the religious repertoire, our paper also aims to show how the change of political regimes during the second half of the $20^{\text {th }}$ century had a qualitative and quantitative influence on the published materials and their contents.

\section{A brief history of the journal}

The journal Biserica Ortodoxă Română [The Romanian Orthodox Church] is the first official Romanian publication with an Orthodox character, established at the initiative of Romania's Primate Metropolitan Nifon Rusailă (1789-1875), following the decision of the Holy Synod of November 17, 1873. A few months later, King Carol I (1866-1914) issued the Decree No. 1125 of May 27, 1874 whereby he approved the publication of the journal, and on September 20, 1874, the first issue of the journal came out, bearing the subtitle Jurnal Periodic Ecleziastic [Periodical Ecclesiastical Journal]. The first editorial committee was composed of the former bishop of Argeș, Ghenadie

\footnotetext{
${ }^{1}$ By 2014, about 23,000 studies, articles, documents, reviews, bibliographic notes, reportages, etc. had been published. Apud Stănciulescu-Bârda, Al., Stănciulescu-Bârda, C. (2014, p. 5).
} 
Ţeposu (chairman), protosingelos Silvestru Balănescu and hierodeacon Ghenadie Enăceanu (members). The journal was published on a monthly basis and was distributed, through archprietships, on a subscription basis - which was mandatory for the personnel of the churches, monasteries and theological schools. From the very first year of publication of the journal, many subscriptions were also made by people from abroad, especially from Transylvania, which was then part of the Austro-Hungarian Empire, given that the topics proposed for the contents of the journal and published in the first issue covered all the aspects discussed within the theological disciplines, along with the important decisions of the Holy Synod, various information reports etc.

During its long existence there were several brief periods of interruption in its publication, due to financial difficulties or to the particular context the entire society was in. Thus, the lack of funds during the War of Independence (1877-1878) prevented its publication between 1878 and 1880. Its publication was resumed due to the support given by the Primate Metropolitan Calinic Miclescu (1822-1886), who established the Printing-House for Church Books, which also took over the publication of the journal, which in 1884 received the subtitle Revistă periodică ecleziastică [Periodical Ecclesiastical Journal]. The same thing happened in 1916, when the Romanian Kingdom entered the First World War. Entitled Revistă a Sfântului Sinod [Journal of the Holy Synod], the journal Biserica Ortodoxă Română [The Romanian Orthodox Church] resumed its appearance on October 1, 1921, during the office of Romania's Primate Metropolitan and future Patriarch Miron Cristea, $\mathrm{PhD}$ (1868-1939). Beginning with 1945, the journal's editorial board was subordinated to the Bible and Mission Institute of the Romanian Orthodox Church, and after the enthronement of Romania's third Patriarch, in 1948 - Justinian Marina (19011977) -, the journal received the subtitle of Buletinul Oficial al Sfântului Sinod [Official Bulletin of the Holy Synod]. In 1953 it was changed into Buletin Oficial al Patriarhiei Române [Official Bulletin of the Romanian Patriarchate], which has been preserved to the present day.

Despite being marked by the political changes of the middle of the last century, the journal managed to survive in the communist years and to gradually return to the level achieved in the interwar period, due to the sustained support from Patriarchs Justinian Marina, Iustin Moisescu and Teoctist Arăpaşu and to the collaboration with prominent theologians such as Priest-Professors Dumitru Stăniloae, Ioan G. Coman, Ene Branişte, Liviu Stan, Mircea Păcurariu, Ion Bria a.o. In the new millennium, more exactly in 2007, the journal entered a process of modernization under the auspices of the His Beatitude Patriarch Daniel, as proven, for example, by the existence of its own site, which allows a quick and wide-range information of the public of all ages and professions. 


\section{Status of the journal in the first years after the proclamation of the Romanian People's Republic}

On December 30, 1947, following the forced abdication of His Majesty King Michael I of Romania, the Romanian People's Republic was proclaimed, which marked the establishment of the communist regime and the abolishment of the 1923 constitution. In the immediate aftermath of the Second World War, having fallen under the sphere of influence of the Soviet Union, the Romanian society began to change radically. The repressive measures taken against those who did not comply with the directives from Moscow dealt a heavy blow to the clergy as well. The effects of Decrees No. 177/1948 - on the general regime of religious denominations - and No. 410/1949 - regarding monastic life are well known. These decrees established the legitimacy of the interference of the state and of the communist party in the activity of the Church, with the government and Great National Assembly being the decision-making forums ${ }^{2}$. In the years that followed, these normative acts deeply affected the entire activity of the Church, which was controlled by the government and by the Great National Assembly. The subscription to the journal became mandatory for all the Romanian parishes, given that, as stated in the March-April 1948 issue, it was "the only official body of the Romanian Patriarchate which published all the church laws and regulations, various normative provisions for the clergy, as well as the debates and decisions of the Holy Synod, which the priests should

2 Below are some illustrative examples from Decree No. 177/1948. Article 21 provided: "The heads of denominations, as well as the metropolitans, archbishops, bishops, superintendents, apostolic administrators, vicar-administrators and others having similar functions, elected or appointed according to the organizing statutes of the respective denominations, will be recognized solely subject to approval of the Presidium of the Great National Assembly, given by decree, at the proposal of the Government, following the recommendation of the Minister of Religion. Before taking office, all of them will swear an oath of allegiance before the Minister of Religion. The oath formula is as follows: «As a servant of God, as a man and as a citizen, I swear to be faithful to the People and to defend the Romanian People's Republic, against any enemy from outside and within; I swear that I shall respect and that I shall ensure that my subordinates respect the laws of the Romanian People's Republic; I swear that I shall not allow my subordinates to start or take part and I shall not start or take part in any action which would affect public order and the integrity of the Romanian People's Republic. So help me God!»”. Article 24 regulated the organization of meetings: "The religious denominations may hold congresses or general assemblies subject to approval by the Ministry of Religion, while the local conferences and meetings (eparchial, parish assemblies), subject to approval of the respective local authorities." Article 56 specified: "All the religious denominations are due to submit their organizational statute in accordance with the provisions of the present law, for approval by the Ministry of Religion, within 3 months from the date of publication of this law. Statute approval is given by decree of the Presidium of the Great National Assembly, at the proposal of the Minister of Cults" (our translation)

http://legislatie.just.ro/Public/DetaliiDocumentAfis/47, accessed: March 20, 2019. 
be knowledgeable of and conform to" (Stănciulescu-Bârda Al., StănciulescuBârda, C., 2016, p. 28). However, if we consider that before 1989, due to censorship, the journal appeared with a delay of almost two years, the role of official press body, which had the mission to inform "on time", is derisory ${ }^{3}$.

A decade of radical changes followed, in which the articles and contents of the journal along with the editorial team changed, according to the provisions of the documents issued by the Romanian Workers' Party, which were, in turn, aligned with the directives coming from the Soviet Union. Although during all this time, chairman of the editorial board was His Beatitude Patriarch Justinian Marina, the journal Biserica Ortodoxă Română [The Romanian Orthodox Church] was also subjected to censorship, like all the other publications.

To understand today what this censorship actually meant, it is enough to randomly open any issue published after the 1948 decree, to see how the contents were adapted to the times and to the ideology coming from the East. Instead of articles on canonical ordinances, denomination, missionary and philanthropic works, scientific articles on theology, reviews or chronicles of church cultural events organized in Romania and in the Christian world, etc. which had been featured in the inter-war issues -, we would find telegrams addressed to the leaders, editorials or pastoral letters speaking about the fight for peace and disarmament, about the cultivation of agricultural fields, about factories and plants etc., because only the politically correct texts were admitted which promoted elements of communist ideology. For example, in issue No. 1-2/1949, which published in full Statutul pentru organizarea și funcționarea Bisericii Ortodoxe Române [Statute for the Organization and Functioning of the Romanian Orthodox Church], a special event was illustrated related to the church's higher education: the opening of the courses of the University Theological Institute in Bucharest, on January $30^{4}$; the issue featured the speeches of the officials present at the inauguration ceremony, led by Patriarch Justinian and Minister Stanciu Stoian. In his speech, the rector of the newly established institution stated that “... the times when theological students were educated by the university of the bourgeois-landlord state in the spirit of isolation from the aspirations of the large masses, of racial hatred and chauvinism, and through methods of sterile abstractions, have passed away forever (our emphasis). The theological school opening its doors

\footnotetext{
${ }^{3}$ The manuscripts were retained at the Department of Religion and submitted to censorship for one year, to be studied and to receive that much expected "ready for print" (StănciulescuBârda, Al. \& Stănciulescu-Bârda, C., 2016, p. 34).

${ }^{4}$ By art. 49 of Decree No. 177 on the general regime of religious denominations, a significant number of higher and pre-university units had been abolished, while the Faculty of Theology in Bucharest was transformed into a Theological Institute of university rank. Only one similar institution was also established in Sibiu.
} 
today is no longer a school of olden times, existing more for itself, within its own walls, without sufficiently and justly seeing the pulsations of the true social life, namely the deep and pure desires of the working people, in their organic connection with the true Christian teaching. Today, a new theological school opens its doors, a school of the right-believing people's Church, a school that will know how to capitalize on the entire social aspect of the Christian doctrine, to give the Church active servants, able to satisfy all the demands of the people's soul" (Statutul [The Statute], 1949, pp. 10-11) (our translation). This indicates that the Church's servants too had to contribute to the formation of the "new man" - in this case, of the future priests - and that the specialized press had to illustrate this process. Thus, all the transformations that the Orthodox Church went through in the following decade are clearly illustrated by the contents of the journal, dominated by regulations regarding the organization of church life; also recounted were the numerous courses meant to train the priests and teachers working in the theological education and to help the clergy in fulfilling their duties within the new society. However, always present from the very first pages of the journal were the telegrams addressed to comrades Gheorghe Gheorghiu-Dej (1901-1965) ${ }^{5}$ and Gheorghe Maurer (1902-2000) ${ }^{6}$, on different occasions - for example December $30^{7}$ or August $23^{8}$-, or on more insignificant occasions.

Although after 1958, the persecutions against intellectuals were resumed, the journal embarked upon a gradual process of reinvigoration, of returning to its original scope after the end of the Stalinist period - as far as times allowed, of course. In addition to articles relating to theological issues, to the clergy's practical activity and to theological education, the journal also included studies on church history or from different fields of theology, but also on national history and church art, reviews or records of various events, in sections such as: "Din trecutul bisericii noastre" [From the Past of Our Church],

\footnotetext{
5 Gheorghe Gheorghiu-Dej was Secretary General of the Romanian Communist Party/Romanian Workers' Party (1945-1965) and President of the Council of Ministers (19611965).

${ }^{6}$ Gheorghe Maurer was President of the Presidium of the Great National Assembly of Romania (1958-1961) and Chairman of the Council of Ministers (Prime Minister) of Romania (19611974).

7 December 30, 1947, the year of proclamation of the Romanian People's Republic was celebrated as the Republic Day.

${ }^{8}$ August 23, 1944 is the date when King Michael I decided to dismiss and arrest General Ion Antonescu, Prime Minister of Romania, to cease collaboration with the Axis Powers and start negotiations with the Allies and the Soviet Union. After 1947, King Michael's contribution was ignored, the merit being attributed to the communists, and the day was regarded as the Armed Insurrection of August 23, 1944, becoming the National Day of Romania. Following the proposal of Nicolae Ceaușescu, it was renamed into the Revolution of Social, National, Antifascist and Anti-Imperialist Liberation.
} 
"Documentare" [Documentaries], "Din viața bisericii" [From the Life of the Church]. For example, in 1959, the journal published the article entitled 600 de ani de la intemeierea Mitropoliei Ungro-Vlahiei [1600 Years from the Establishment of the Metropolitan See of Ungro-Wallachia] (I.P.S: Justinian, pp. 665-672), and a year later, Pr. Gabriel Cocora wrote about Tipografia și tipăriturile de la Episcopia Buzăulu [Typography and Prints from the Bishopric of Buzău] (1960, pp. 286-331), while D. Bărbulescu brought Completări și îndreptări la bibliografia românească veche [Additions and Corrections to the Old Romanian Bibliography] (1960, pp. 545-559). In 1962, two articles were published signed by Pr. Paulin Popescu, in which the Putna codices are mentioned. First, Manuscrise slavone din Mînăstirea Putna [Slavonic Manuscripts from the Putna Monastery] (1962, pp. 275-290 and pp. 535-557), followed by an article entitled Mărcile de hârtie filigranate pe manuscrisele slavone din Minăstirea Putna [The Watermarks on the Slavonic Manuscripts from the Putna Monastery] (1962, pp. 938-957). At the same time, however, from 1959 until the years when Nicolae Ceaușescu was at the helm of the Romanian Communist Party, a new column appeared constantly in each issue: "În apărarea păcii" [In the Defence of Peace]. With the same regularity, the issues 9-10 of each year included a section entitled "Luna prieteniei româno-sovietice" [The Month of the Romanian-Soviet Friendship], which disappeared only in 1964. This was the year when Gheorghiu-Dej - Secretary General of the Communist Party and President of the Council of Ministers summoned the Soviet ambassador to Bucharest, on October 21, and demanded the withdrawal of the KGB advisers from Romania (Bărbulescu, M. et al, 2002, p. 409); the situation was resolved in the sense desired by the Romanian side, at the end of the year, after several talks and discussions between Gheorghe Gheorghiu-Dej and Leonid Brejnev, who had taken the place of Nikita Khrushchev in the leadership of the U.S.S.R. communist party.

A few lines taken from the editorial published on the occasion of the anniversary of two decades since its release, in 1964, are edifying for the language that dominated the period, which had to be adopted by theological journals as well: "August 23 is rightfully the most important national holiday of the Romanian people. It is a landmark between two eras and divides the history of our country and people into two eras: before August 23, 1944 and after August 23, 1944. It brings a dark age to an end, while opening wide horizons for a bright era, loaded with secure prospects of a prosperous life stemming from the free and enthusiastic work of a people in control of their fate, of the riches of their country and of the fruits of their creative efforts..." (our translation). Year after year, these editorials ended invariably with a kind of commitment that the Church would "eagerly" participate in the celebration of the Romanian people, "while also renewing the holy promise that in future too, hierarchs, clergy and believers will ardently participate, alongside the 
people, in any action meant to ensure the blossoming of the homeland and the public welfare, as a contribution to the peace of the entire world" (p. 983) (our translation).

It should be noted that although these texts, along with the telegrams addressed to the party and state leaders or the articles on the activity of the Council of Ministers and Great National Assembly changed the profile and quality of the journal, the journal continued to be published, gathering in its pages many valuable studies.

\section{Articles about music published between 1948 and 1989}

A simple inventory of the music-related materials published in the journal Biserica Ortodoxă Română [The Romanian Orthodox Church] highlights the progress of the journal in terms of contents, in relation to the political situation of the country during the second half of the $20^{\text {th }}$ century. These materials were published in 139 issues and include reviews, concert reviews or musical texts. These musical texts began to be published in the Appendix, with the first printed score dating from 1970: Gheorghe Cucu, Cântările Sfintei Liturghii [Chants of the Divine Liturgy], with a preface by N. Lungu (Anexa [Appendix], pp. I-LXXX).

We have followed the changes that occurred from one decade to the next regarding the number and themes of the articles. For the $6^{\text {th }}$ decade we have also considered the years 1948-1950, but we have found that during that period the journal was forced to illustrate the legislative changes, while the editorial space was occupied mainly by texts of various regulations and norms regarding the life and work of the parish priests, as well as the training of the new Church leaders and of the teaching staff working in theological schools.

While the first music-related articles appeared only in 1952, by studying the contents of the previous issues, we have found that the substantial theological studies, such as those from the interwar period, also began to appear only in the $7^{\text {th }}$ decade, i.e. in a period when the Soviet pressure had quieted down. It is therefore not surprising that only 8 materials were published in the first communist decade of the journal's publication (more precisely, between 1952 and 1960), among which 2 reviews and two concert/festival reviews.

The period was dominated by articles on the standardization of church chants, which emphasized the benefits of joint singing and the need for an appropriate repertoire to that purpose. The decision of the Holy Synod of June 1952 regarding the introduction of a unique repertoire for use in church services all over the country was immediately followed by an article signed by Nicolae Lungu. The music teacher from the Theological Institute in Bucharest - who, in 1951, along with two fellow brothers, had published the theoretical work designed to aid in the learning of psaltic musical notation (Lungu, N. 
Costea, G., Croitoru, I., 1951) and had engaged himself in the standardization of the chant repertoire -, wrote an extensive article entitled Cântarea în comun ca mijloc de lămurire a dreptei credințe [Joint Chanting as a Means of Understanding the Orthodox Faith] (1952, pp. 890-899). It was a plea for the generalization of joint chanting, which was aided by the standardized repertoire, with simplified melodic lines written in simultaneous notation (overlapping neumes and staves), which could be easily deciphered and learned by parishioners. In the following year, the idea was supported by Bishop Antim Târgovișteanu in the article entitled Despre cântarea credincioșilor în biserică [About the Believers' Singing in Church] (1953, pp. 1118-1123).

The article published four years later by Șt. C. Alexe, Foloasele cântării în comun după Sfântul Niceta de Remesiana [The Benefits of Joint Chanting According to Saint Nicetas of Remesiana], made an indirect reference to this theme, bringing into discussion the benefits of joint chanting. The articles and reviews published in 1958 show that the problem of standardized singing was not yet fully clarified. On page 129 of the 1st-2nd issue, the editorial office published a note entitled Muzica bisericească în atenția Sanctității Sale Patriarhului Ecumenic [Church Music in the Attention of His All-Holiness Ecumenical Patriarch], and a few issues later a short article was published signed by priest Olimp Căciulă: În legătură cu muzica bisericească [In the Matter of Church Music] (1958, pp. 816-817). This is also proven by the two reviews (signed A.G.), one on Priest Ion Runcu's book - Cântări liturgice în stil psaltic [Liturgical Chants in Psaltic Style] (1960, pp. 753-754) - and the other one on the collection entitled Cântările Sfintei Liturghii și podobiile celor opt glasuri [The Chants of the Holy Liturgy and the Prosomia of the Eight Tones], entitled $O$ nouă contribuție la uniformizarea muzicii bisericești [A New Contribution to the Standardization of Church Music] (1960, pp. 755758). We should also note that this joint chanting, promoted insistently through all the means, was also meant to compensate for the lack of service officiants, whose number had decreased due to the abolition of the singers' schools and to the repressive measures applied during those years of establishment and stabilization of the atheist state.

We can therefore see that a certain political relaxation which occurred after Stalin's death (1953), along with the gradual estrangement from Moscow had a positive influence on the contents of the journal and favoured the publication of some fundamental studies on the valuable musical manuscripts kept in the Romanian libraries, during the following decades. On the other hand, the intensification of the research on church music, especially on this national treasure represented by the Byzantine musical manuscripts, was possible due to the emphasis placed at the time by the Romanian Communist Party on the values of the national culture. At the same time, the development of Byzantine musicology in the 7th to 9th decades of the last century is largely 
indebted to musicologist Titus Moisescu who, in his capacity as director of Editura Muzicală [the Musical Publishing House] for nearly two decades, knew how to combat censorship by highlighting precisely the heritage value of the old documents, their importance as proofs of the perenniality of the Romanian people in the geographical territory of contemporary Romania and their contribution to the universal culture, which arguments were accepted due to Nicolae Ceaușescu's particular sensitivity for this subject.

Therefore, the research on the music of Byzantine tradition was, surprisingly, gradually resumed, and the musicians who in their youth had studied in theological seminars or had led a monastic life, were able to express their passion for church music, to use and enrich their knowledge and to approach this area of research. An impulse in this respect was the 1967 publication of Father Ioan D. Petrescu's book, Études de paléographie musicale [Musical Palaeography Studies] (1967 - after a long wait for the approval for publication, as the volume had been ready since as early as $1958^{9}$. The appearance of the book is signalled in the journal Biserica Ortodoxă Română [the Romanian Orthodox Church], in a review entitled O lucrare monumentală despre muzica bizantină [A Monumental Work on Byzantine Music] signed by Popescu Gabriel (1967, pp. 1057-1059) ${ }^{10}$.

The musicology articles published in the journal in the $8^{\text {th }}$ decade reflect the concern of the few researchers in the field for promoting the musical manuscripts of Byzantine tradition from the national libraries, especially those written by Romanians. Between 1971 and 1980, the journal published 33 articles and reviews related to church music. At the same time, 22 issues of the journal also included musical compositions.

In 1969, four major studies appeared as a preamble to the "explosion" of articles during the $8^{\text {th }}$ decade. First, in the $3^{\text {rd }}$ and $4^{\text {th }}$ issues, deacon Grigore Panțiru wrote an article entitled Necesitatea și actualitatea cercetării științifice a vechii muzici bizantine [Necessity and Topicality of the Scientific Research on Old Byzantine Music], while in the successive issues published during the second half of the year, three other important texts were published. Thus, Sebastian Barbu-Bucur (then teacher at a music school in Bucharest) drew attention to the first manuscript with Byzantine notation and Romanian text, Psaltichia [Book of Psaltic Music] written by Filothei Jipa in 1713. Then, Gheorghe Ciobanu wrote Anton Pann și "românirea" cântărilor bisericești [Anton Pann and the "Romanianization" of Church Chants] (1969, pp. 1154-

\footnotetext{
${ }^{9}$ See, in this regard, Titus Moisescu (1999). Preotul Ioan D. Petrescu-Visarion. Ctitor al Școlii românești de muzică bizantină [Priest Ioan D. Petrescu-Visarion. Founder of the Romanian School of Byzantine Music], in Monodia bizantină în gândirea unor muzicieni români [Byzantine Monody in the Conception of Romanian Musicians]. București: Editura Muzicală.

${ }^{10}$ Gabriel Popescu, O lucrare monumentală despre muzica bizantină [A Monumental Work on Byzantine Music], Year LXXXV (1967), No. 9-10, pp. 1057-1059.
} 
1160), while deacon Grigore Panţiru brought into discussion the Putna manuscripts (1969, pp. 1257-1264), which would be the main object of study for several years, especially for Titus Moisescu, but also for Gheorghe Ciobanu, who in 1966 had already published a study on the Music School from Putna in the "Muzica" [Music] journal (1966, pp. 14-20).

A year later (1970), the hymn dedicated to St. John the New of Suceava was highlighted in the journal of the Patriarchate (Smochină, Panțiru, 1970, pp. 602-606), and in 1972, a synthesis study by Gheorghe Ciobanu was published in the same journal: Muzica bisericească la români [Romanian Church Music] (pp. 162-195). A first doctoral thesis dedicated to musical manuscripts by Father Nicu Moldoveanu was published in the same journal in 1974: Izvoare ale cântării psaltice în Biserica Ortodoxă Română. Manuscrisele muzicale vechi bizantine din România (grecești, româno-grecești), până la începutul secolului al XIX-lea [Sources of the Psaltic Chant in the Romanian Orthodox Church. The Old Byzantine Musical Manuscripts from Romania (Greek, Romanian-Greek), until the Beginning of the $19^{\text {th }}$ Century] (pp. 131-280). Until the end of the decade, Father Sebastian Barbu-Bucur, who published several studies on the process of "Romanianization" of church chants, was joined by other important names such as Deacon Ion Popescu, and Pr. Prof. Marin Velea.

The most prolific period for musical studies was between 1971 and 1980, when the journal's pages hosted 60 articles, studies, reviews and scores, of which more than 30 were important contributions to the history of church music in Romania, while more than 20 were musical (especially choral) compositions. In the following decades, there was a considerable decrease in the number of studies, probably because the musicology journals (Studii de muzicologie [Musicology Studies], Lucrări de muzicologie [Musicology Papers], Muzica [Music]), along with the journal of the Institute of Art History sponsored by the Romanian Academy (Studii şi cercetări de istoria artei [Studies and Research in Art History]) began to also include studies on church music, under the "umbrella" of the phrase "Byzantine music". A part of the studies was also published in the metropolitan journals. In addition to that, in 1976, the appearance of the series Izvoare ale muzicii românești [Sources of Romanian Music] also offered an opportunity for affirmation of the research in Byzantine musicology through the publication of several volumes of medieval musical manuscripts, in documenta and transcripta variants; the photocopies of the manuscripts were preceded, in most cases, by consistent studies signed by Gheorghe Ciobanu and Titus Moisescu.

Between 1981 and 1989, the journal published several studies by Pr. Prof. Nicu Moldoveanu, PhD. In the March-April 1984 issues, he used the investigations conducted as a recipient of a scholarship offered by the Ecumenical Patriarchate of Constantinople at Hochschule fur Musik und darstellende Kunst in Vienna in the article Cercetări asupra manuscriselor în 
notație bizantină existente în Biblioteca Națională din Viena [Research on the Manuscripts in Byzantine Notation from the National Library in Vienna. Byzantine Manuscripts from Romania and by Romanian Authors]. However, he also addressed the issue of church music in contemporary times, in two articles: Muzica bisericească la români în sec. XX [Romanian Church Music in the $20^{\text {th }}$ Century] (1985, pp. 615-636) and Creația corală bisericească la români în sec. al XX-lea [Choral Church Music in $20^{\text {th }}$-Century Romania] (pp. 117-139). Besides a few reviews published in the journal during this period, Pr. Prof. Marin Velea, Ph.D. also published a study entitled Gavriil Musicescu dirijor și compozitor de muzică corală bisericească [Gavriil Musicescu Conductor and Composer of Choral Church Music] (1982, pp. 984-989).

We note that in those years, other materials were also allowed to be published related to the activity of composers who contributed to the enrichment of the church repertoire during the first half of the $20^{\text {th }}$ century. We are referring here to two articles signed by Gheorghe Vasilescu, which bring to the fore the personalities of Gheorghe Cucu (Documente inedite privitoare la viața și activitatea compozitorului Gheorghe Cucu [Unpublished Documents Regarding the Life and Work of Composer Gheorghe Cucu], 1982, pp. 719730) and Dumitru Georgescu Kiriac (Precizări documentare privind activitatea compozitorului D. G. Kiriac [Documentary Details Regarding the Activity of Composer D. G. Kiriac], 1986, pp. 134-153).

Beginning with 1980, Editura Muzicală [the Musical Publishing House] had published annually, for five years, a volume dedicated to the Putna manuscripts, under the headline Izvoare ale muzicii românești [Sources of Romanian Music]. The importance of this monastic establishment is revealed to the journal's readers by Pr. Marin Velea in 1984, in the article Școala muzicală de la Putna în context general românesc și balcanic (sec. XV-XVI) [The Music School from Putna in a Romanian and Balkan General Context $\left(15^{\text {th }}-16^{\text {th }}\right.$ c. $)$ (pp. 232-237).

The last article of the communist period was published in 1988 by Archd. Sebastian Barbu-Bucur, Ph.D., who, on his return from the specialized courses he had attended in Greece - on which occasion he had visited the Athonite monastic libraries several times -, synthesized the information on a personality of church music about which there was little information in Romania and wrote the article entitled Iovașcu Vlahul. Protopsaltul curții Ungrovlahiei și epoca sa in manuscrisele de la Muntele Athos [Iovașcu the Vlach. Protopsaltes at the Ungro-Wallachian Court and His Epoch in the Manuscripts of Mount Athos].

We shall make one more remark before concluding the presentation of the materials related to church music, published during the communist period. In the $8^{\text {th }}$ decade, a sign of the changes in the party's politics was also the fact that in 1974, the journal's pages included news about a Christmas carol concert held at the Romanian Patriarchate, and, a year later, about another one held 
under a generic that in earlier days would not have been allowed under the existing censorship: Iată, vine Moș Crăciun! [Here Comes Santa Claus!] because the celebration of Christ's Nativity, popularly called Christmas, was banned. Officially, the winter holidays were linked to December 30, the day of proclamation of the Romanian People's Republic, when schools and institutions organized festivities where children received gifts from Grandfather Frost, the communist equivalent of Santa Claus. Around the same period, the journal also published carols harmonized by priest Iulian Cârstoiu (in the 1973 and 1977 issues).

\section{Musical Works Published during the Communist Period}

For the presentation of the articles on church music published in the journal Biserica Ortodoxă Română [The Romanian Orthodox Church], we have used the same delimitation on a decade basis, because the strategy of the editorial team also applied to this area of manifestation of those who published in the journal.

As expected, the first finding is that the $6^{\text {th }}$ decade of the last century was not favourable to musical composition, which is easily understandable. In the years that followed, given the need to popularize certain works through the journal that was distributed to all the parishes, a decision was made to add an Appendix at the end of the journal. Periodically, the journal published scores of choral or psaltic religious works, as well as reworkings of folk songs - mostly carols. By 1964, the magazine had already published Imnul patriarhal [Patriarchal Hymn] by Pr. Ion Runcu (pp. 446-450). Other works followed, among which, in 1970, Cântările Sfintei Liturghii [Chants of the Holy Liturgy] by Gheorghe Cucu (1970), and another variant thereof, in tone 3, by Pr. Iulian Cârstoiu (1971), followed in 1986 by Liturghia în stil psaltic [Liturgy in Psaltic Style] composed by Paul Constantinescu. In general, the communist period was dominated by the choral chant - original works or reworkings and harmonizations of psaltic chants composed by Nicolae Lungu, Nicu Moldoveanu, Ioan Gh. Popescu.

What draws our attention for the following decade (1981-1990) is the return to the traditional psaltic works, adapted to the Romanian language by Hieromonk Macarie, Dimitrie Suceveanu and Ion Popescu-Pasărea, published in 1988, 1989 and 1990. It is known that the standardization of church chants had not achieved the expected success, as each historical region of the country had preserved its own tradition and repertoire, established in churches for almost a century. In this context, the somewhat official re-circulation of that repertoire confirmed what was going on in churches and, at the same time, stimulated that tendency by offering valuable musical material, which was sometimes difficult to access because of the scarcity of old books of church chants composed by leading representatives of the Romanian psaltic music. 


\section{Musicological research and musical compositions during the first decade of democracy}

The restoration of democracy in Romania, at the end of 1989, brought important changes regarding the publications of the Orthodox Church. In the atmosphere of excitement of those days, within a week, i.e. on December 29, 1989, a new journal appeared: Vestitorul Ortodoxiei Românești [The Herald of Romanian Orthodoxy $]^{11}$, in which Archd. Sebastian Barbu-Bucur, Ph.D., published a psaltic composition: Rugăciune [Prayer] on verses by Vasile Militaru (1990). At the same time, the distinguished priest-professor offered his compositions for publication in the journal Biserica Ortodoxă Română (The Romanian Orthodox Church], in the $3^{\text {rd }} 4^{\text {th }}$ issues of 1990: Cântări la inmormântare și parastas [Chants for Funerals and Memorial Services] (pp. IXXXII, Anexă [Appendix]).

In the field of musicology, we find several authors who published during this period. In this respect, Prof. Vasile Vasile, Ph.D. had a very active presence in the journal's pages, with two reviews and three studies on major representatives of Romanian psaltic music. He wrote about Ion PopescuPasărea, on the $50^{\text {th }}$ anniversary of his death $-O$ viață în slujba muzicii bisericești: Ion Popescu-Pasărea (1871-1943) [A Life in the Service of Church Music: Ion Popescu-Pasărea (1871-1943)] (pp. 111-116), about Hieromonk Macarie in Activitatea muzicală a lui Macarie Ieromonahul la Mânăstirea Neamt [The Musical Activity of Hieromonk Macarie at the Neamț Monastery] (pp. 278-293) and about the Romanian monk Schemamonk Nektarios, chanter and composer living on Mount Athos (pp. 464-472).

To resume the chronological presentation, we mention the study entitled Afirmarea muzicii românești în vremea domniei lui Al. I. Cuza (1859-1866) [Romanian Music During the Reign of Al. I. Cuza (1859-1866)], (1991, pp. 121-154). The great chanter Ion Popescu-Pasărea was honoured in the journal's pages in 1993 also by Constantin C. Ionescu, who referred to him as the national pedagogue of our church music (pp. 92-98). In 1995, Archd. Sebastian Barbu-Bucur, Ph.D., published the study Manuscrise psaltice românești în biblioteci străine [Romanian Psaltic Manuscripts in Foreign Libraries] (pp. 267-272), making a synthetic presentation of the documents preserved on Mount Athos, in Copenhagen, Leningrad, Belgrade, Sofia, Athens, as well as in other collections of church books. This was a new opportunity to appreciate the contribution of the Romanian chanters and copyists to the perpetuation of the Byzantine musical tradition. A year later, Pr. Prof. Alexie Buzera, Ph.D.,

11 "Until the middle of 1992, the periodical kept its original name: Vestitorul Ortodoxiei Românești [The Herald of Romanian Orthodoxy]. Then, for a year, it was named simply Vestitorul [The Herald]. As of its $94^{\text {th }}$ issue (May 15, 1993), its name was established and has been preserved to this day as: Vestitorul Ortodoxiei [The Herald of Orthodoxy]." https://vestitorulortodoxiei.ro/istoric/ (our translation) 
from the Faculty of Orthodox Theology in Craiova, brought to the readers' attention the lesser-known figure of Ghelasie the Bessarabian, by presenting his biography and his printed or manuscript chants and also by compiling a catalogue of his works (1996, pp. 382-394).

As far as musical compositions are concerned, between 1989 and 2000, the journal's Appendix contained only two: the already mentioned chants for funerals and memorial services of Pr. Sebastian Barbu-Bucur and a variant of the Lamentations over the Dead Christ, composed by Nicolae Ionescu-Palas, Ph.D. and Pr. Prof. Nicu Moldoveanu (1999, pp. I-LVIII, Appendix). In the following decade, however, church music composition manifested with greater force, both in terms of choral and psaltic music.

\section{Conclusions}

Among the church periodicals, the journal Biserica Ortodoxă Română [The Romanian Orthodox Church] stands out by its longevity and by the valuable content of a significant part of its issues published over almost a century and a half. The journal also often included musical studies, reviews of music-related books, scores or articles on church music history etc. Although their number seems insignificant, if we compare it to the totality of titles in the journal in terms of themes approached and originality of information, many of the studies and articles published in this Buletin Oficial al Patriarhiei Române [Official Bulletin of the Romanian Patriarchate] contributed to a better knowledge of church music. During the period when the atheist state strongly opposed to everything that had to do with religion, the journal of the Romanian Patriarchate offered space for the publication of materials that could not be published in lay journals.

Despite the unfavourable political context of the communist period, in which most of the church publications had been abolished, the journal's publication sustained the continuation of the research on musical palaeography by hosting numerous of studies related to the Byzantine musical manuscripts. The published articles often brought clarifications and completions regarding the history of music in the Romanian space during the medieval period, and revealed representative figures of church music, personalities of the time who were recognized for their talent and works and who contributed to the perpetuation of the Orthodox musical tradition. Thus, some of the materials published in the journal during the second half of the $20^{\text {th }}$ century ensured the development of the research on the church music of the previous three decades, serving as bibliographic sources for the current studies.

The political transformations of the mid- $20^{\text {th }}$ century influenced the production of articles and musical composition, with the articles on music being sporadic until the $7^{\text {th }}$ decade, and musical composition being completely 
absent. The $8^{\text {th }}$ decade was the most prolific one, both in terms of musicology and of musical composition.

The authors who published the most valuable studies and articles in this journal are those who, after 1990, contributed to the training of new generations of specialists in the field of church music, either directly, as teachers, or through their works, research models and important bibliographical sources.

\section{References}

A[lexe], G. (1960). Cântări liturgice în stil psaltic. Recenzie la cartea pr. Ion Runcu [Liturgical Chants in Psaltic Style. Review of Pr. Ion Runcu's Book]. Biserica Ortodoxă Română ["Romanian Orthodox Church" Journal], Year LXVIII (1960), 7-8, 753-754. București.

A[lexe], G. (1960). O nouă contribuție la uniformizarea muzicii bisericești [A New Contribution to the Standardization of Church Music]. Biserica Ortodoxă Română ["Romanian Orthodox Church" Journal], Year LXVIII (1960), 7-8, 755-758. București.

Alexe, Șt. C. (1957). Foloasele cântării în comun după Sfântul Niceta de Remesiana [The Benefits of Joint Chanting According to Saint Nicetas of Remesiana]. Biserica Ortodoxă Română ["Romanian Orthodox Church" Journal], Year LXXV (1957), 1-2, 165-182. București.

Barbu-Bucur, S. (1969). Monumente muzicale. Filothei sin Agăi Jipei. Prima psaltichie românească cunoscută până acum (1713) [Musical Monuments. Filothei sin Agăi Jipei. The First Psaltic Music Manual Known So Far (1713)]. Biserica Ortodoxă Română ["Romanian Orthodox Church" Journal], Year LXXXVII (1969), 9-10, 10661075. București.

Barbu-Bucur, S. (1988). Iovașcu Vlahul. Protopsaltul curții Ungrovlahiei și epoca sa în manuscrisele de la Muntele Athos. [Iovașcu the Vlach. Protopsaltes at the UngroWallachian Court and His Epoch in the Manuscripts of Mount Athos]. Biserica Ortodoxă Română ["Romanian Orthodox Church" Journal], Year C VI (1988), 7-8, 62-104. București.

Barbu-Bucur, S., Archd. (1990). Rugăciune [Prayer]. Vestitorul Ortodoxiei Românești [The Herald of Romanian Orthodoxy Journal], Year II, 13-14. București.

Barbu-Bucur, S., Archd. (1990). Cântări la înmormântare și parastas [Chants for Funerals and Memorial Services]. Biserica Ortodoxă Română ["Romanian Orthodox Church" Journal], Year CVIII (1990), 3-4 (March-Apr.), I-XXXII (Anexa [Appendix]). București.

Barbu-Bucur, S., Archd. (1995). Manuscrise psaltice românești în biblioteci străine [Romanian Psaltic Manuscripts in Foreign Libraries]. Biserica Ortodoxă Română ["Romanian Orthodox Church" Journal], Year CXIII (1995), 1-6, 267-272. București. 
Bărbulescu, D. (1960). Completări și îndreptări la bibliografia românească veche [Additions and Corrections to the Old Romanian Bibliography]. Biserica Ortodoxă Română ["Romanian Orthodox Church" Journal], Year LXXVIII (1960), 5-6, 545559. București.

Bărbulescu, M.\& Deletant, D. \& Hitchins, K. \& Papacostea, Ș. \& Teodor, P. (2002). Istoria României [The History of Romania], București: Corint.

Buzera, Al. (1996). Ghelasie Basarabeanul. Contribuții [Ghelasie the Bessarabian. Contributions]. Biserica Ortodoxă Română ["Romanian Orthodox Church" Journal], Year CXIV (1996), 7-12, 382-394. București.

Căciulă, O. (1958). În legătură cu muzica bisericească [In the Matter of Church Music]. Biserica Ortodoxă Română ["Romanian Orthodox Church" Journal], Year LXXXVI (1958), 9, 816-817. București.

Ciobanu, Gh. (1969). Anton Pann și « românirea » cântărilor bisericești [Anton Pann and the «Romanianization» of Church Chants]. Biserica Ortodoxă Română ["Romanian Orthodox Church" Journal], Year LXXXVII (1969), 10-11, 1154-1160. București.

Ciobanu, Gh. (1966). Școala muzicală de la Putna [The Music School from Putna]. Muzica ["Music" Journal], Year XVI (1966), 9, 14-20. București.

Ciobanu, Gh. (1972). Muzica bisericească la români [Romanian Church Music]. Biserica Ortodoxă Română ["Romanian Orthodox Church" Journal], Year XC (1972), 1-2, 162-195. București.

Cocora, G. (1960). Tipografia și tipăriturile de la Episcopia Buzăului [Typography and Prints from the Bishopric of Buzău]. Biserica Ortodoxă Română ["Romanian Orthodox Church" Journal], Year LXXVIII (1960), 3-4, 286-331. București.

Cucu, Gh. (1964). Cântările Sfintei Liturghii [The Chants of the Divine Liturgy Biserica Ortodoxă Română ["Romanian Orthodox Church" Journal], Year LXXXVIII, 3-4, Anexa [Appendix], I-LXXX. București.

Ionescu, C. C. (1993). Profesorul Ion Popescu-Pasărea, pedagog național al muzicii noastre bisericești [Professor Ion Popescu-Pasărea, The National Pedagogue of Our Church Music]. Biserica Ortodoxă Română ["Romanian Orthodox Church" Journal], Year XCIII, 4-6, 92-98. București.

Lungu, N. \& Costea, G. \& Croitoru I. (1951). Gramatica muzicii psaltice. Studiu comparat cu notația lineară [The Grammar of Psaltic Music. Comparative Study with Linear Notation]. București: Editura Institutului Biblic.

Lungu, N. (1952). Cântarea în comun ca mijloc de lămurire a dreptei credințe [Joint Chanting as a Means of Understanding the Orthodox Faith]. Biserica Ortodoxă Română ["Romanian Orthodox Church" Journal], Year LXX (1952), 11-12, 890-899. București. 
Ionescu-Palas N. \& Moldoveanu, N. (1999). Prohodul Domnului [Lamentations over the Dead Christ]. Biserica Ortodoxă Română ["Romanian Orthodox Church" Journal], Year CXVII (1999), 1-6, I-LVIII (Anexă [Appendix]). București.

Marina, J., patriarch (1959). 600 de ani de la întemeierea Mitropoliei Ungro-Vlahiei [1600 Years from the Establishment of the Metropolitan See of Ungro-Wallachia]. Biserica Ortodoxă Română ["Romanian Orthodox Church" Journal], Year LXXVII (1959), 7-8. București.

Moisescu, T. (1999). Preotul Ioan D. Petrescu-Visarion. Ctitor al Școlii românești de muzică bizantină [Priest Ioan D. Petrescu-Visarion. Founder of the Romanian School of Byzantine Music]. In Monodia bizantină în gândirea unor muzicieni români [Byzantine Monody in the Conception of Romanian Musicians]. București: Editura Muzicală.

Moldoveanu, N. Pr. (1974). Izvoare ale cântării psaltice în Biserica Ortodoxă Română. Manuscrisele muzicale vechi bizantine din România (grecești, româno-grecești), până la începutul secolului al XIX-lea [Sources of the Psaltic Chant in the Romanian Orthodox Church. The Old Byzantine Musical Manuscripts from Romania (Greek, Romanian-Greek), until the Beginning of the $19^{\text {th }}$ Century], PhD Thesis. Biserica Ortodoxă Română ["Romanian Orthodox Church" Journal], Year XVII (1974), 1-2, 131-280. București.

Moldoveanu, N. Pr. (1974). Cercetări asupra manuscriselor în notație bizantină existente în Biblioteca Națională din Viena. Manuscrise bizantine provenite din România și autori români [Research on the Manuscripts in Byzantine Notation from the National Library in Vienna. Byzantine Manuscripts from Romania and by Romanian Authors]. Biserica Ortodoxă Română ["Romanian Orthodox Church" Journal], Year CII, 3-4, 238-245. București.

Moldoveanu, N. Pr. (1985). Muzica bisericească la români în sec. XX [Romanian Church Music in the $20^{\text {th }}$ Century]. Biserica Ortodoxă Română ["Romanian Orthodox Church" Journal], Year CIII (1985), 7-8, 615-636. București.

Moldoveanu, N. Pr. (1974). Creația corală bisericească la români în sec. al XX-lea [Romanian Choral Church Music in the $20^{\text {th }}$ Century]. Biserica Ortodoxă Română ["Romanian Orthodox Church" Journal], Year CIV, 3-4, 117-139. București.

Moldoveanu, N. Pr. (1991). Afirmarea muzicii românești în vremea domniei lui Al. I. Cuza (1859-1866) [Romanian Music During the Reign of Al. I. Cuza (1859-1866)]. Biserica Ortodoxă Română ["Romanian Orthodox Church" Journal], Year CIX, 4-6, 121-154. București.

Panțiru G. (1969). Necesitatea și actualitatea cercetării științifice a vechii muzici bizantine [The Need and Topicality of the Scientific Research on Old Byzantine Music]. Biserica Ortodoxă Română ["Romanian Orthodox Church" Journal], Year LXXXVII (1969), 3-4, 434-441. București.

Panțiru, G., dea. (1969). Manuscrisele muzicale inedite de la Mănăstirea Putna [The Unpublished Musical Manuscripts from the Putna Monastery]. Biserica Ortodoxă 
Română ["Romanian Orthodox Church" Journal], Year LXXXVII (1969), 11-12, 1257-1264. București.

Petrescu, I. D. (1967). Études de paléographie musicale [Musical Palaeography Studies]. București: Editura Muzicală.

Popescu, G. (1976). O lucrare monumentală despre muzica bizantină [A Monumental Work on Byzantine Music]. Biserica Ortodoxă Română ["Romanian Orthodox Church" Journal], Year LXXXV, 9-10, 1057-1059. București.

Popescu, P. (1962 a). Manuscrise slavone din Mănăstirea Putna, I [Slavonic Manuscripts from the Putna Monastery, I]. Biserica Ortodoxă Română ["Romanian Orthodox Church" Journal], Year LXXX (1962), 5-6, 275-290. București.

Popescu, P. (1962 b). Manuscrise slavone din Mînăstirea Putna, II [Slavonic Manuscripts from the Putna Monastery, II]. Biserica Ortodoxă Română ["Romanian Orthodox Church” Journal], Year LXXX (1962), 7-8, 535-557. București.

Popescu, P. (1962 c). Mărcile de hârtie filigranate pe manuscrisele slavone din Mînăstirea Putna [The Watermarks on the Slavonic Manuscripts of the Putna Monastery]. Biserica Ortodoxă Română ["Romanian Orthodox Church" Journal], Year LXXX (1962), 9-10. București.

Runcu, I. pr. (1964). Imn Patriarhal [Patriarchal Hymn]. Biserica Ortodoxă Română ["Romanian Orthodox Church" Journal], Year LXXXII (1964), 5-6, 446-450. București.

Smochină N. \& Panțiru, G., dea. (1970). Un vechi imn despre Sfầntul Ioan cel Nou de la Suceava [An Old Hymn to Saint John the New from Suceava]. Biserica Ortodoxă Română ["Romanian Orthodox Church" Journal], Year LXXXVIII (1970), 5-6, 602606. București.

Stănciulescu-Bârda, Al. \& Stănciulescu-Bârda, C. (2016). Bibliografia revistei Biserica Ortodoxă Română (1874-2014) [Bibliography of the "Romanian Orthodox Church” Journal (1874-2014)], I. Malovăț: Editura Cuget Românesc.

Târgovișteanu, A., bishop (1953). Despre cântarea credincioșilor în biserică [About the Believers' Singing in Church]. Biserica Ortodoxă Română ["Romanian Orthodox Church" Journal], Year LXXI (1953), 11-12, 1118-1123. București.

Vasile, V. (1993). O viață în slujba muzicii bisericești: Ion Popescu-Pasărea (18711943) [A Life in the Service of Church Music: Ion Popescu-Pasărea (1871-1943)]. Biserica Ortodoxă Română ["Romanian Orthodox Church" Journal], Year CXI (1993), 10-12, 111-116. București.

Vasile, V. (1997). Activitatea muzicală a lui Macarie Ieromonahul la Mănăstirea Neamț [The Musical Activity of Hieromonk Macarie at the Neamț Monastery]. Biserica Ortodoxă Română ["Romanian Orthodox Church" Journal], Year CXV (1997), 7-12, 278-293. București.

Vasile, V. (1999). Nectarie Vlahul, figură reprezentativă a muzicii bisericești din secolul al XIX-lea [Nektarios the Vlach, a Prominent Figure of $19^{\text {th }}$-Century Church 
Music]. Biserica Ortodoxă Română ["Romanian Orthodox Church" Journal], Year CXVII, 7-12, 464-472. București.

Vasilescu, Gh. (1982). Documente inedite privitoare la viața și activitatea compozitorului Gheorghe Cucu [Unpublished Documents Regarding the Life and Work of Composer Gheorghe Cucu], Biserica Ortodoxă Română ["Romanian Orthodox Church" Journal], Year C (1982), 7-8, 719-730. București.

Vasilescu, Gh. (1986). Precizări documentare privind activitatea compozitorului D. G. Kiriac [Documentary Details Regarding the Activity of Composer D. G. Kiriac]. Biserica Ortodoxă Română ["Romanian Orthodox Church" Journal], Year CIV (1986), 5-6, 134-153. București.

Velea M. pr. (1982). Gavriil Musicescu - dirijor şi compozitor de muzică corală bisericească [Gavriil Musicescu - Conductor and Composer of Choral Church Music]. Biserica Ortodoxă Română ["Romanian Orthodox Church" Journal], Year C (1982), 11-12, 984-989. București.

Velea M., pr. (1984). Școala muzicală de la Putna în context general românesc și balcanic (sec. XV-XVI) [The Music School from Putna in a Romanian and Balkan General Context]. Biserica Ortodoxă Română ["Romanian Orthodox Church" Journal], Year CII (1984), 3-4, 232-237. București.

*** (1964) Editorial [Editorial]. Biserica Ortodoxă Română ["Romanian Orthodox Church" Journal], Year LXXXII (1964), 7-8, 983. Bucharest.

*** (1958) Nota redacției [Editor's Note]. Muzica bisericească în atenția Sanctității Sale Patriarhului Ecumenic [Church Music in the Attention of His All-Holiness Ecumenical Patriarch]. Biserica Ortodoxă Română ["Romanian Orthodox Church" Journal], Year LXXXVI (1958), 1-2, 129. București.

*** (1949) Statutul pentru organizarea și functionarea BOR [Statute for the Organization and Functioning of the Romanian Orthodox Church]. Biserica Ortodoxă Română ["Romanian Orthodox Church" Journal], Year LXVI (1949), 1-2, Appendix. București.

***Decretul nr. 177/1948 [Decree No. 177/1948]. Retrieved from

http://legislatie.just.ro/Public/DetaliiDocumentAfis/47, accessed: 20 March, 2019.

https://vestitorulortodoxiei.ro/istoric/

***https://www.academia.edu/18699014/CERCETARILE_DE_MUZICOLOGIE_BI ZANTINA_IN_ROMANIA_TOTALITARA 